\title{
Cytotoxic Activity and Chemical Composition of the Root Extract from the Mexican Species Linum scabrellum: Mechanism of Action of the Active Compound 6-Methoxypodophyllotoxin
}

\author{
Ivonne Alejandre-García, ${ }^{1}$ Laura Álvarez, ${ }^{2}$ Alexandre Cardoso-Taketa, ${ }^{1}$ \\ Leticia González-Maya, ${ }^{3}$ Mayra Antúnez, ${ }^{2}$ Enrique Salas-Vidal, ${ }^{4}$ J. Fernando Díaz, ${ }^{5}$ \\ Silvia Marquina-Bahena, ${ }^{2}$ and María Luisa Villarreal ${ }^{1}$ \\ ${ }^{1}$ Centro de Investigación en Biotecnología, Universidad Autónoma del Estado de Morelos, Avenida Universidad 1001, \\ Colonia Chamilpa, 62209 Cuernavaca, MOR, Mexico \\ ${ }^{2}$ Centro de Investigaciones Químicas IICBA, Universidad Autónoma del Estado de Morelos, Avenida Universidad 1001, \\ Colonia Chamilpa, 62209 Cuernavaca, MOR, Mexico \\ ${ }^{3}$ Facultad de Farmacia, Universidad Autónoma del Estado de Morelos, Avenida Universidad 1001, Colonia Chamilpa, \\ 62209 Cuernavaca, MOR, Mexico \\ ${ }^{4}$ Instituto de Biotecnología, Universidad Nacional Autónoma de México, 62209 Cuernavaca, MOR, Mexico \\ ${ }^{5}$ Centro de Investigaciones Biológicas, Madrid 28040, Spain
}

Correspondence should be addressed to Silvia Marquina-Bahena; smarquina21@hotmail.com and María Luisa Villarreal; luisav@uaem.mx

Received 31 March 2015; Revised 26 May 2015; Accepted 3 June 2015

Academic Editor: Shrikant Anant

Copyright (C) 2015 Ivonne Alejandre-García et al. This is an open access article distributed under the Creative Commons Attribution License, which permits unrestricted use, distribution, and reproduction in any medium, provided the original work is properly cited.

The cytotoxic activity and the chemical composition of the dichloromethane/methanol root extract of Linum scabrellum Planchon (Linaceae) were analyzed. Using NMR spectra and mass spectrometry analyses of the extract we identified eight main constituents: oleic acid (1), octadecenoic acid (2), stigmasterol (3), $\alpha$-amyrin (4), pinoresinol (5), 6 methoxypodophyllotoxin (6), coniferin (7), and 6-methoxypodophyllotoxin-7-O- $\beta$-D-glucopyranoside (8). By using the sulforhodamine B assay, an important cytotoxic activity against four human cancer cell lines, HF6 colon $\left(\mathrm{IC}_{50}=0.57 \mu \mathrm{g} / \mathrm{mL}\right), \mathrm{MCF} 7$ breast $\left(\mathrm{IC}_{50}=0.56 \mu \mathrm{g} / \mathrm{mL}\right), \mathrm{PC} 3 \mathrm{prostate}$ $\left(\mathrm{IC}_{50}=1.60 \mu \mathrm{g} / \mathrm{mL}\right)$, and SiHa cervical $\left(\mathrm{IC}_{50}=1.54 \mu \mathrm{g} / \mathrm{mL}\right)$, as well as toward the normal fibroblasts line HFS-30 IC ${ }_{50}=1.02 \mu \mathrm{g} / \mathrm{mL}$ was demonstrated. Compound 6 (6-methoxypodophyllotoxin) was responsible for the cytotoxic activity exhibiting an $\mathrm{IC}_{50}$ value range of 0.0632 to $2.7433 \mu \mathrm{g} / \mathrm{mL}$ against the tested cell lines. Cell cycle studies with compound 6 exhibited a cell arrest in G2/M of the prostate PC3 cancer cell line. Microtubule disruption studies demonstrated that compound $\mathbf{6}$ inhibited the polymerization of tubulin through its binding to the colchicine site (binding constant $K_{b}=7.6 \times 10^{6} \mathrm{M}^{-1}$ ). A dose-response apoptotic effect was also observed. This work constitutes the first investigation reporting the chemical composition of L. scabrellum and the first study determining the mechanism of action of compound $\mathbf{6}$.

\section{Introduction}

The genus Linum of the Linaceae family includes more than 200 globally distributed species. The phytochemical profiles that have been reported for the species of Linum suggest the presence of some lignan-type secondary metabolites [1].
These kinds of compounds show several important pharmacological activities such as transcriptase reverse inhibition and HIV activity, effects on cardiovascular system, antileishmaniasis properties, hypoglycemic activities, 5-lipoxygenase inhibition, and antifungal, antirheumatic, antipsoriasis, antimalarial, and antiasthmatic properties [2-14]. However, 
cytotoxic and antitumoral activities are a major interest on these types of lignans [15]. Podophyllotoxin (PTOX) is the most important aryltetralin-lignan for human health in relation to anticancer and antiviral activities. It is used for the treatment of genital warts (condyloma acuminata) caused by the human papilloma virus [15] and for the semisynthesis of the two important antineoplastic agents etoposide and teniposide, which are actually used in the treatment of several cancers, among others: acute myeloid leukemia, Hodgkin's disease, non-Hodgkin's lymphoma, lung cancer (both small cell and non-small cell), gastric cancer, breast cancer, and ovarian cancer [16].

Some species of Linum as L. persicum and L. nodiflorum accumulate PTOX [17], while others as L. flavum, L. mucronatum ssp. armenum, L. capitatum, L. arboretum, L. campanulatum, L. elegans, L. pamphylicum, L. tauricum, L. thracicum, L. sibiricum, and $L$. nodiflorum accumulate 6-methoxypodophyllotoxin (6MPTOX) [18]. The mechanism of action of PTOX is based on the inhibition of tubulin polymerization through interaction with the binding site of colchicine [19] as well as on the arrest of the cell cycle in metaphase [2022]. Although the compound 6MPTOX has been reported with cytotoxic activity against murine Ehrlich ascites and HeLa cervix uteri neoplastic cell lines, its mechanism of action is unknown. Others derivatives as desmethoxy-yatein and desoxypodophyllotoxin are responsible for cytotoxic and antitumoral activities $[23,24]$. The analogue $4^{\prime}$-demethylepipodophyllotoxin inhibits DNA topoisomerase II $[16,24]$, and several series of nonlactonic podophyllic aldehyde analogues produce apoptosis induction of neoplastic cells without a previous tubulin inhibition [25].

In Mexico 28 species of Linum have been identified, of which 12 are endemic. The species of Linum are used in Mexican Traditional Medicine to treat respiratory infections, snake bites, malaria, leishmaniasis, gastrointestinal affections, inflammation, and cystitis as well as other conditions [26-29].

Linum scabrellum is a perennial herb endemic to Mexico that grows up to 40 or $50 \mathrm{~cm}$, pubescent in its green parts with leaves alternated and flowering from June to December [28]. It is distributed in 7 states of the country: Querétaro, Guanajuato, Hidalgo, Oaxaca, Puebla, Nuevo León, and Tamaulipas. In a previous study, we reported the cytotoxic activity of three extracts (chloroform, butanol, and aqueous) prepared from aerial parts and roots of L. scabrellum against three human cancer cell lines. The obtained results showed that the most toxic activity was observed from the root's chloroformic extract against KB (epidermoid), HF6 (colon), and MCF7 (breast) carcinomas, exhibiting $\mathrm{IC}_{50}$ values that ranged from 0.2 to $4.8 \mu \mathrm{g} / \mathrm{mL}$ [30].

The aim of the present investigation was to study the chemical composition of Linum scabrellum and to identify its cytotoxic constituents. This is the first phytochemical study that reports the complete metabolic content of this species that allowed the identification of 6MPTOX as the active metabolite against human cancer cell lines. In order to explore the mechanism of action of this compound, several studies were conducted to determine its effects on the cell cycle progression of PC3 prostate cancer cells, mitotic arrest, microtubule polymerization, binding affinity to tubulin, and cell death.

\section{Materials and Methods}

2.1. Plant Material. The wild plant Linum scabrellum was collected by M.S. Ivonne Alejandre García on November 2012 at $5 \mathrm{~km}$ to the south of Vizarrón, Cadereyta Queretaro, Mexico. A sample was authentified by BS Alejandro Flores and deposited at the HUMO Herbarium of the Universidad Autónoma del Estado de Morelos (UAEM), with the voucher number 27194.

2.2. Preparation of Extracts. The collected plant material was air dried and grounded using an electric mill (749 g), and four extracts of L. scabrellum were obtained with solvents of different polarity (hexane, ethyl acetate, dichloromethane, and methanol). The extracts of dichloromethane and methanol exhibited the major content of secondary metabolites; nonpolar metabolites were present in the dichloromethane extract while polar metabolites were in the methanol extract. The grounded plant was extracted with $\mathrm{CH}_{2} \mathrm{Cl}_{2}: \mathrm{MeOH}$ $(50 / 50 \mathrm{v} / \mathrm{v})$, in order to obtain the majority of the compounds, and sonicated during $30 \mathrm{~min}(\times 3)$. The extract was concentrated in a Buchi rotary evaporator at $40^{\circ} \mathrm{C}$ and stored at room temperature for further chemical fractionation. The extract yield was $19.4 \mathrm{~g}$.

2.3. Isolation of Compounds. Compounds were isolated by means of open column chromatography (CC). The isolation procedures and purity of compounds were checked by thin layer chromatography (TLC), visualized by means of UV light, and sprayed with $\mathrm{Ce}\left(\mathrm{SO}_{4}\right)_{2} \cdot 2\left(\mathrm{NH}_{4}\right)_{2} \mathrm{SO}_{4} \cdot 2 \mathrm{H}_{2} \mathrm{O}$. The UV spectra were recorded on a Hewlett Packard 8452A spectrophotometer. All ${ }^{1} \mathrm{H},{ }^{13} \mathrm{C}$, and $2 \mathrm{D}$ NMR experiments were recorded in $\mathrm{CDCl}_{3}$, acetone- $d_{6}$, and $\mathrm{CD}_{3} \mathrm{OD}$ on a Varian Unity 400 spectrometer at $400 \mathrm{MHz}$ for ${ }^{1} \mathrm{H} \mathrm{NMR}$, and at $100 \mathrm{MHz}$ for ${ }^{13} \mathrm{C}$ NMR. FABMS spectra were recorded on a JEOL JMX-AX 505 HA mass spectrometer. The IR spectrum was recorded on a Perkin Elmer FTIR spectrophotometer (Perkin Elmer, USA) using $\mathrm{KBr}$, measured in $\mathrm{cm}^{-1}$. Melting points were determined on a Fisher-Johns Melting Point apparatus. Optical rotations were measured on a Perkin-Elmer 341 digital polarimeter at $25^{\circ} \mathrm{C}$. All the reagents and solvents used were of analytical grade. The $\mathrm{CH}_{2} \mathrm{Cl}_{2}: \mathrm{MeOH}$ extract $(19.4 \mathrm{~g})$ was fractionated in an open chromatographic column $(60 \mathrm{~cm} \times 9 \mathrm{~cm})$ previously packed with silica gel (582 g, 70-230 mesh; Merck) and eluted with a dichloromethane/methanol gradient system, starting with $100 \%$ of the less polar solvent and subsequently increasing the methanol. Seventy-eight fractions of $100 \mathrm{~mL}$ each were collected and concentrated by vacuum distillation and grouped according to their chemical content as monitored by TLC. Eight groups of fractions were obtained: F-1 (1.3 g, $100: 0)$, F-2 (2.5 g, $98: 2)$, F-3 (1.0 g, $96: 4)$, F-4 (1.82 g, $94: 6)$, F-5 (3.71 g, 92:8), F-6 (2.88 g, $90: 10)$, F-7 (2.75 g, $85: 15)$, and F-8 $(0.90 \mathrm{~g}, 0: 100)$. In the less polar fraction (F-1) oleic acid (1, $180 \mathrm{mg})$ and octadecenoic acid (2, $320 \mathrm{mg}$ ) were 
identified. After a successive chromatographic process using $\mathrm{CH}_{2} \mathrm{Cl}_{2}: \mathrm{MeOH}$ gradient system, F-2 (100:00 $\left.\rightarrow 97: 03\right)$ yielded stigmasterol $(3,25 \mathrm{mg})$ and $\alpha$-amyrin $(4,14 \mathrm{mg})$, F-5 (100:00 $\rightarrow 85: 15)$ afforded pinoresinol (5, $4.9 \mathrm{mg}$ ), 6-methoxypodophyllotoxin (6, $40 \mathrm{mg})$, and coniferin $(7,6.5 \mathrm{mg})$ and F-6 $(100: 00 \rightarrow 80: 20)$ yielded 6methoxypodophyllotoxin-7-O- $\beta$-D-glucopyranoside $503.1 \mathrm{mg})$.

2.4. Cytotoxic Assay. The $\mathrm{CH}_{2} \mathrm{Cl}_{2}: \mathrm{MeOH}$ of aerial and root extracts as well as compounds $\mathbf{6}, \mathbf{7}$, and $\mathbf{8}$ were subjected to a cytotoxic evaluation using breast (MCF7), colon (HF6), prostate (PC3), and cervical ( $\mathrm{SiHa}$ ) human cancer cell lines from ATCC (American Type Culture Collection, USA), along with normal human fibroblast cells (HSF-30) at passage number 33 (In Vitro Co.). Cell cultures were grown in RPMI-1640 medium (Sigma Aldrich) supplemented with fetal bovine serum $10 \%$ (SFB, Invitrogen), $\mathrm{NaHCO}_{3} 7.5 \%$, and cultivated in 96-well plates $\left(10^{4}\right.$ cells $\left./ \mathrm{mL}\right)$ at $37^{\circ} \mathrm{C}$ with $\mathrm{CO}_{2}$ $5 \%$ (humidity $100 \%$ ). Normal human fibroblasts were grown in DMEM medium (Invitrogen) supplemented with fetal bovine serum $10 \%$. The cells in a log phase of their growth cycle were treated in triplicate with various concentrations of the test samples $(0.16-20 \mu \mathrm{g} / \mathrm{mL})$ dissolved in dimethyl sulfoxide (DMSO, Sigma Aldrich) and incubated for $72 \mathrm{~h}$ in the conditions described above. In order to guarantee that the cells were in exponential growth, the criteria of confluence between $60-70 \%$ were adopted. The cell concentration was determined by the NCI sulforhodamine method [31]. The results were expressed as the dose that inhibits $50 \%$ control growth after the incubation period $\left(\mathrm{IC}_{50}\right)$. The values were estimated from a log 10 plot of the drug concentration against the percentage of viable cells. The standards included as controls were PTOX and Taxol (Sigma Aldrich). Extracts with $\mathrm{IC}_{50} \leq 20 \mu \mathrm{g} / \mathrm{mL}$ and compounds with $\mathrm{IC}_{50} \leq 4 \mu \mathrm{g} / \mathrm{mL}$ were considered active according to the National Cancer Institute (NCI) guidelines [32]. The data analysis was processed using the program ORIGIN 8.0, IC $_{50}$ values were obtained by a regression curve with coefficient factors $R^{2}$ between 0.80 and 0.99 .

2.5. Cell Cycle Analysis. Prostate cancer cells PC3 $\left(1 \times 10^{5}\right)$ were plated in 6-well plates and allowed to attach overnight at $37^{\circ} \mathrm{C}$ in $5 \% \mathrm{CO}_{2}$. Exponential growing cells were exposed at four different concentrations of 6MPTOX in accordance with IC $_{50}$ values $(0.011 \mu \mathrm{M}, 0.005 \mu \mathrm{M}, 0.002 \mu \mathrm{M}$, and $0.001 \mu \mathrm{M})$ for $72 \mathrm{~h}$. Cells from each treatment were trypsinized and collected into single cell suspensions, centrifuged, and fixed in cold ethanol $(70 \%)$ overnight at $-20^{\circ} \mathrm{C}$. The cells were then treated with RNase $(0.01 \mathrm{M}$, Sigma Aldrich) and stained with propidium iodide (PI) $(7.5 \mu \mathrm{g} / \mathrm{mL}$, Invitrogen) for $30 \mathrm{~min}$ in the dark, PI has the ability to bind to DNA molecules, and then RNase was added in order to allow PI to bind directly to DNA. The percentage of cells in G1, S, and G2 phases was analyzed with a flow cytometer (Becton, Dickinson, FACS Calibur, San Jose, CA); the number of cells analyzed for each sample was 10,000. Data obtained from the flow cytometer were analyzed using the FlowJo Software (Tree
Star, Inc., Ashland, OR, USA) to generate DNA content frequency histograms, and to quantify the number of cells in the individual cell cycle phases.

2.6. Immunofluorescence of Histone H3 Phosphorylated. PC3 cells were grown in RPMI medium, and $7.5 \times 10^{4}$ cells were added in 24-well culture plates containing slides and allowed to attach overnight at $37^{\circ} \mathrm{C}$ in $5 \% \mathrm{CO}_{2}$. Then, they were treated with 6MPTOX $(0.005 \mu \mathrm{M})$, PTOX $(0.002 \mu \mathrm{M})$, and DMSO $(2.25 \mu \mathrm{M})$ at $37^{\circ} \mathrm{C}$ for $72 \mathrm{~h}$. The cells were fixed with PFA ( $p$-formaldehyde) $4 \%$ in PEM buffer PIPES (0.1 M), EGTA (2 mM), and $\mathrm{MgSO}_{4}(1 \mathrm{mM}), \mathrm{pH}$ 6.95. After $15 \mathrm{~min}$ $\mathrm{PFA} / \mathrm{NaHCO}_{3}$ was added and incubated for $45 \mathrm{~min}$ at room temperature. The slides were rinsed with PBS, treated with 0.1\% Triton X-100 (Sigma Aldrich), and then incubated with the primary antibody antiphospho-histone H3 (1:500, Santa Cruz Biotechnology) overnight at $4^{\circ} \mathrm{C}$. A secondary antibody anti-rabbit Alexa 488 (1:1000, Molecular Probes) was added and incubated for $1 \mathrm{~h}$ at $37^{\circ} \mathrm{C}$. The cells were stained with $0.4 \mu \mathrm{g} / \mathrm{mL}$ 4,6-diamidino-2-phenylindole (DAPI, Molecular Probes, Eugene, OR) in PBS for $10 \mathrm{~min}$, then mounted, and imaged by fluorescence microscopy.

2.7. Immunofluorescence of $\alpha$-Tubulin. PC3 cells were grown in RPMI medium, and $7.5 \times 10^{4}$ cells were added in 24 well culture plates containing slides and allowed to attach overnight at $37^{\circ} \mathrm{C}$ in $5 \% \mathrm{CO}_{2}$. Then they were treated with 6MPTOX $(0.005 \mu \mathrm{M})$, PTOX $(0.002 \mu \mathrm{M})$, and DMSO $(2.25 \mu \mathrm{M}-0.02 \%)$ at $37^{\circ} \mathrm{C}$ for $72 \mathrm{~h}$. The cells were fixed with PFA (paraformaldehyde) 4\% in PEM (buffer). After $15 \mathrm{~min}$ $\mathrm{PFA} / \mathrm{NaHCO}_{3}$ was added and incubated for $45 \mathrm{~min}$ at room temperature. The slides were rinsed with PBS and treated with $0.1 \%$ Triton X-100 (Sigma Aldrich) and then incubated with the first antibody anti- $\alpha$-tubulin (1:300, Sigma Aldrich) overnight at $4^{\circ} \mathrm{C}$. A second antibody anti-mouse Alexa 647 (1:1000, Molecular Probes) was added and incubated for two hours at $37^{\circ} \mathrm{C}$. The cells were stained with Sytox Green (1:5000) for one hour, mounted, and imaged by confocal microscopy.

2.8. Determination of the Binding Site and Affinity Constant $K_{b}$. The binding affinity constant $\left(K_{b}\right)$ of 6MPTOX was determined following the method described previously [33]. Displacement of the colchicine analogue MTC [2-methoxy5-(2,3,4-trimethoxyphenyl)-2,4,6-cycloheptatrien-1-one], a commercial reversible tubulin ligand in the colchicine site that binds to the heterodimer $\alpha / \beta$ tubulin, was evaluated. Initially, mixtures of tubulin and MTC $(5 \mu \mathrm{M})$ were incubated in $10 \mathrm{mM}$ of buffer $\mathrm{GAB}$ ( $\mathrm{NaPi}$ with $0.1 \mathrm{mM}$ GTP and $\mathrm{pH}$ 7). Subsequently, increasing concentrations of the above tested compound and controls were added and incubated for $10 \mathrm{~min}$ between each concentration at $25^{\circ} \mathrm{C}$ in the fluorometer Horiba Fluoromax-2, with $\lambda$ exc $=350 \mathrm{~nm}$ and $\lambda \mathrm{em}=423 \mathrm{~nm}$. Binding constants were calculated by the decrease of the fluorescence of MTC due to competition for the same site. Data processing was analyzed using the Equigra v5 software [34]. 
TABLE 1: $\mathrm{IC}_{50}$ values $(\mu \mathrm{g} / \mathrm{mL})$ of dichloromethane/methanol extract and 6MPTOX isolated from Linum scabrellum.

\begin{tabular}{lcccrr}
\hline Extract/compound & PC3 & MCF7 & Cell lines & SiHa & HFS-30 \\
\hline $\mathrm{CH}_{2} \mathrm{Cl}_{2}: \mathrm{MeOH}$ extract & $1.60 \pm 0.07$ & $5.7 \times 10^{-1} \pm 0.07$ & $5.7 \times 10^{-1} \pm 0.07$ & $1.54 \pm 0.07$ & $1.02 \pm 0.07$ \\
6MPTOX & $1.7 \times 10^{-1} \pm 0.07$ & $6.6 \times 10^{-2} \pm 0.07$ & $7.9 \times 10^{-2} \pm 0.07$ & $2.74 \pm 0.07$ & $6.0 \times 10^{-2} \pm 0.07$ \\
PTOX & $3 \times 10^{-3} \pm 0.07$ & $1 \times 10^{-4} \pm 0.07$ & $1.4 \times 10^{-3} \pm 0.07$ & $1.23 \pm 0.07$ & $1 \times 10^{-4} \pm 0.07$ \\
Taxol & $6.2 \times 10^{-1} \pm 0.07$ & $1.3 \times 10^{-1} \pm 0.07$ & $2.8 \times 10^{-1} \pm 0.07$ & $2.30 \pm 0.07$ & $1.2 \times 10^{-1} \pm 0.07$ \\
\hline
\end{tabular}

PC3: prostate cancer, MCF7: breast cancer, HF6: colon cancer, SiHa: cervical cancer, and HFS-30: fibroblasts.

2.9. Cell Death. PC3 cells $\left(7.5 \times 10^{4}\right.$ cells $\left./ \mathrm{mL}\right)$ were seeded in 6-well plates and incubated for $18 \mathrm{~h}$. Exponentially growing cells were treated for $72 \mathrm{~h}$ with RPMI medium added with $0.02 \%$ of DMSO (control) and with four different concentrations of $6 \mathrm{MPTOX}(0.011 \mu \mathrm{M}, 0.005 \mu \mathrm{M}, 0.002 \mu \mathrm{M}$, and $0.001 \mu \mathrm{M})$ in accordance with the $\mathrm{IC}_{50}$ value of the compound. Cells treated with $\mathrm{H}_{2} \mathrm{O}_{2}$ were used as apoptotic death control [35] and for the necrotic control PC3 cells were treated with boiling water. Then, each cell culture was washed with $100 \mathrm{~mL}$ of PBS and stained with $100 \mu \mathrm{L}$ $\mathrm{AO} / \mathrm{EB}$ solution $(100 \mu \mathrm{g} / \mathrm{mL} \mathrm{AO}, 100 \mu \mathrm{g} / \mathrm{mL} \mathrm{EB})$, according to reported procedures [36]. The cells were observed using a fluorescence microscope (Olympus Co., Tokyo, Japan, with emission at $521 \mathrm{~nm}$ ). AO/EB are intercalating nucleic acidspecific fluorochromes, and when bounded to DNA they emit green and orange fluorescence, respectively. It is well known that AO can pass through cell membranes, but EB cannot. Under the fluorescence microscope, living cells appear green. Necrotic cells stain red but have a nuclear morphology resembling that of viable cells. Apoptotic cells appear green, and morphological changes such as formation of apoptotic bodies are observed. The criteria for identification are as follows: (i) viable cells appear to have green nucleus with intact structure; (ii) early apoptosis cells exhibit a brightgreen nucleus showing condensation of chromatin; (iii) late apoptosis appears as dense orange areas of chromatin condensation; and (iv) orange intact nucleus depicts secondary necrosis [37].

\section{Results and Discussion}

3.1. Cytotoxic Activity and Chemical Composition of Linum scabrellum. The $\mathrm{CH}_{2} \mathrm{Cl}_{2}$ : $\mathrm{MeOH}$ extract from aerial parts was noncytotoxic to the tested cell lines $\left(\mathrm{IC}_{50} \leq 20 \mu \mathrm{g} / \mathrm{mL}\right.$ ). The $\mathrm{CH}_{2} \mathrm{Cl}_{2}: \mathrm{MeOH}$ roots extract of $L$. scabrellum presented cytotoxic activity against the four carcinoma cell lines exhibiting $\mathrm{IC}_{50}$ values from 0.56 to $1.54 \mu \mathrm{g} / \mathrm{mL}$ as well as toward the normal cell line with an $\mathrm{IC}_{50}$ value of $1.02 \mu \mathrm{g} / \mathrm{mL}$ (Table 1 ). The first complete phytochemical profile of L. scabrellum was established in order to identify the cytotoxic metabolites. In the $\mathrm{CH}_{2} \mathrm{Cl}_{2}$ :MeOH extract, eight compounds were identified and characterized (Figure 1), three of them (5, 6, and 8) belong to the lignan group. Four compounds, oleic acid (1), octadecenoic acid (2) stigmasterol (3), and $\alpha$-amyrin (4), were identified by their spectroscopic data ${ }^{1} \mathrm{H}$ and ${ }^{13} \mathrm{C}$ and cochromatography with authentic samples available on our laboratory. The other four compounds were identified by their spectroscopic data ${ }^{1} \mathrm{H},{ }^{13} \mathrm{C}$ NMR, spectra mass, mp, UV, IR, and 2D experiments (COSY, HSQC) as follows: F-5 was subjected to column chromatography packed with silica gel (115 g) and eluted with a gradient system of $\mathrm{CH}_{2} \mathrm{Cl}_{2}: \mathrm{MeOH}$ $(100: 00 \rightarrow 90: 10)$ obtaining 46 fractions of $25 \mathrm{~mL}$ each and were grouped in six groups according to their similarity in thin layer chromatography $(\mathrm{F}-5 \mathrm{~A} \rightarrow \mathrm{F}-5 \mathrm{~F})$.

Fraction F-5B eluted with 98:02 $\mathrm{CH}_{2} \mathrm{Cl}_{2}: \mathrm{MeOH}$ afforded $4.9 \mathrm{mg}$ of pinoresinol (5), isolated as amorphous powder, $\mathrm{mp}$ 121-22 ${ }^{\circ} \mathrm{C}$ (lit: $122^{\circ} \mathrm{C}$ ) an optically active powder $[\alpha]_{\mathrm{D}}^{24}-82.3^{\circ}$ (c $0.012, \mathrm{Me}_{2} \mathrm{CO}$ ), and had the formula $\mathrm{C}_{20} \mathrm{H}_{22} \mathrm{O}_{6}$ derived from its positive FABMS $[\mathrm{M}+\mathrm{H}]^{+}$ion at $m / z 359$. IR $(\mathrm{KBr}$, $v_{\max }$ in $\left.\mathrm{cm}^{-1}\right): 3210,2870,1600,14651050$. UV $\lambda_{\max }(\mathrm{nm}): 232$, and 280. ${ }^{1} \mathrm{H} \mathrm{NMR}\left(400 \mathrm{MHz}, \mathrm{CDCl}_{3}\right) \delta_{\mathrm{H}}: 6.89(d, J=1.2 \mathrm{~Hz}$; $\left.\mathrm{H}-2, \mathrm{H}-2^{\prime}\right), 6.88\left(d, J=8.4 \mathrm{~Hz} ; \mathrm{H}-5, \mathrm{H}-5^{\prime}\right), 6.81(d d, J=2.1$ and $8.4 \mathrm{~Hz}$; H-6, H- $\left.6^{\prime}\right), 4.73\left(d, J=4.2 \mathrm{~Hz}\right.$; H-7, H-7 $\left.{ }^{\prime}\right), 3.09$ (c, $\left.\mathrm{H}-8, \mathrm{H}-8^{\prime}\right), 4.24\left(d d, J=7\right.$ and $\left.9.1 \mathrm{~Hz} ; 9-\mathrm{H} \beta, 9^{\prime}-\mathrm{H} \beta\right), 3.87(d d$, $J=3.5$ and $9.1 \mathrm{~Hz}$; $\left.9-\mathrm{H} \alpha, 9^{\prime}-\mathrm{H} \alpha\right), 3.90$ ( $\left.s, \mathrm{C} 3^{\prime}-\mathrm{OMe}, \mathrm{C} 3-\mathrm{OMe}\right)$. ${ }^{13} \mathrm{C} \mathrm{NMR}\left(100 \mathrm{MHz} \mathrm{CDCl}_{3}\right) \delta_{\mathrm{C}}: 132.90\left(\mathrm{C}-1, \mathrm{C}-1^{\prime}\right), 108.57(\mathrm{C}-$ 2, C-2' $), 146.68\left(\mathrm{C}-3, \mathrm{C}-3^{\prime}\right), 145.22\left(\mathrm{C}-4, \mathrm{C}-4^{\prime}\right), 114.24(\mathrm{C}-5$, C-5 $\left.5^{\prime}\right), 118.96\left(\mathrm{C}-6, \mathrm{C}^{\prime} 6^{\prime}\right), 85.86\left(\mathrm{C}-7, \mathrm{C}-7^{\prime}\right), 54.16\left(\mathrm{C}-8, \mathrm{C}-8^{\prime}\right)$, $71.66\left(\mathrm{C}-9, \mathrm{C}-9^{\prime}\right)$. On the basis of the spectral data, compound 5 was identified as (-)-pinoresinol [38].

One of the fractions F-5C eluted with 96:04 $\mathrm{CH}_{2} \mathrm{Cl}_{2}: \mathrm{MeOH}$ yielded $40 \mathrm{mg}$ of compound $\mathbf{6}$, obtained as a white amorphous powder, $\mathrm{mp} 202-203^{\circ} \mathrm{C}$ (lit: $203^{\circ} \mathrm{C}$ ). The positive FABMS spectrum showed the $[\mathrm{M}+\mathrm{H}]^{+}$ion peak at $m / z 445$ with molecular formula $\mathrm{C}_{23} \mathrm{H}_{24} \mathrm{O}_{9}$. IR $\left(\mathrm{KBr}, v_{\max }\right.$ in $\mathrm{cm}^{-1}$ ): $3220,1768,1600$. UV $\lambda_{\max }(\mathrm{nm}): 272$, and $282 .{ }^{1} \mathrm{H}$ NMR (400 MHz, acetone- $\left.\mathrm{d}_{6}\right) \delta_{\mathrm{H}}: 6.30(\mathrm{~s}, \mathrm{H}-3), 5.03(d, J$ $=9.8 \mathrm{~Hz}, \mathrm{H}-7), 2.88(m, \mathrm{H}-8), 4.06(d d, J=8.4$ and $10 \mathrm{~Hz}$; $\mathrm{H}-9 \beta), 4.64(t, J=7.7$ and $8.4 \mathrm{~Hz} ; \mathrm{H}-9 \alpha), 6.44\left(s, \mathrm{H}-2^{\prime}, \mathrm{H}-6^{\prime}\right)$, $4.53\left(d, J=4.9 \mathrm{~Hz}, \mathrm{H}-7^{\prime}\right), 2.75(d d, J=4.2$ and $14.7 \mathrm{~Hz}$; $\mathrm{H}-8^{\prime}$ ), 3.78 ( $\left.s, \mathrm{C}^{\prime}{ }^{-}-\mathrm{OMe}, \mathrm{C}^{\prime}-\mathrm{OMe}\right), 3.81\left(s, \mathrm{C} 4^{\prime}-\mathrm{OMe}\right), 3.78$ (s, C6-OMe), 5.95 (s,-O-CH $2-\mathrm{O}-) .{ }^{13} \mathrm{C} \mathrm{NMR}(100 \mathrm{MHz}$, acetone- $\left.\mathrm{d}_{6}\right) \delta_{\mathrm{C}}: 124.93(\mathrm{C}-1), 137.04$ (C-2), 104.36 (C-3), 149.45 (C-4), 132.84 (C-5), 141.57 (C-6), 70.52 (C-7), 39.01 (C-8), 71.92 (C-9), $134.71\left(\mathrm{C}-1^{\prime}\right), 108.09\left(\mathrm{C}-2^{\prime}\right), 152.61\left(\mathrm{C}-3^{\prime}\right)$, $\left.134.93\left(\mathrm{C}-4^{\prime}\right), 152.61 \mathrm{C}-5^{\prime}\right), 108.09\left(\mathrm{C}-6^{\prime}\right), 45.11\left(\mathrm{C}-7^{\prime}\right), 44.53$ $\left(\mathrm{C}-8^{\prime}\right), 174.44\left(\mathrm{C}-9^{\prime}\right), 56.18\left(\mathrm{C}^{\prime}-\mathrm{OMe}\right), 60.77$ (C4'-OMe), 56.18 (C5'-OMe), 59.93 (C6-OMe), 101.37 (-O-CH2-O-). On the basis of the spectral data, compound 6 was identified as 6-methoxypodophyllotoxin [39].

Fraction F-5C eluted with $90: 10 \mathrm{CH}_{2} \mathrm{Cl}_{2}: \mathrm{MeOH}$ yielded $6.5 \mathrm{mg}$ of coniferin (7), obtained as an amorphous solid, $\mathrm{mp}$ 180-82 ${ }^{\circ} \mathrm{C}$ [lit: $\left.182^{\circ} \mathrm{C}\right]$. Positive FABMS $m / z 342[\mathrm{M}+\mathrm{H}]^{+}$, with molecular formula $\mathrm{C}_{16} \mathrm{H}_{22} \mathrm{O}_{8}$. IR $\left(\mathrm{KBr}, v_{\max }\right.$ in $\left.\mathrm{cm}^{-1}\right)$ : 3020 , 
<smiles>CCCCCCCC/C=C/CCCCCCCC(=O)CO</smiles>

(1)<smiles>CCCCCCCCCCCCCCC/C=C/C(=O)O</smiles>

(2)<smiles>CCC(/C=C/C(C)C1CCC2C1CCC1C3CCC(O)CC3=CCC12)C(C)C</smiles>

(3)<smiles>COc1cc([C@H]2OC[C@H]3[C@H](c4ccc(O)c(OC)c4)OC[C@H]23)ccc1O</smiles>

(5)<smiles>C[C@H]1CC[C@]2(C)CC[C@]3(C)C(=CCC4[C@@]5(C)CC[C@@H](O)C(C)(C)C5CC[C@]43C)C2[C@@H]1C</smiles>

(4)

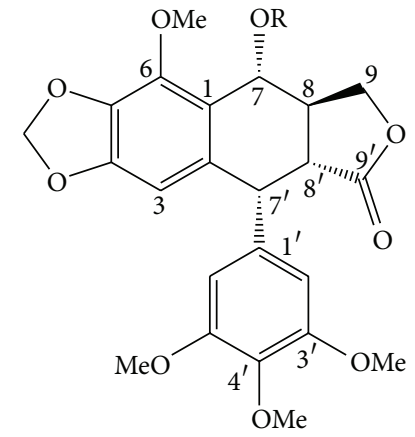

$\mathrm{R}$

(6) $\mathrm{H}$

(8) $-\beta$-D-Glucoside<smiles>COc1cc(/C=C/CO)ccc1O[C@H](O)[C@H](O)[C@H](O)[C@H](O)CO</smiles>

(7)

FIGURE 1: Chemical structure of Linum scabrellum secondary metabolites.

1060, 940. UV $\lambda_{\max }$ (nm): 256 and 292. $[\alpha]^{24}-66.3$ (c 0.010, $\left.\mathrm{Me}_{2} \mathrm{CO}\right) .{ }^{1} \mathrm{H} \mathrm{NMR}\left(400 \mathrm{MHz}, \mathrm{CDCl}_{3}\right) \delta_{\mathrm{H}}: 7.07(d, J=2.4 \mathrm{~Hz}$; $\mathrm{H}-3), 6.89(d d, J=1.6$ and $8 \mathrm{~Hz}$; H-5), $7.09(d, J=8 \mathrm{~Hz} ; \mathrm{H}-$ $6), 6.52\left(d, J=15.2 \mathrm{~Hz} ; \mathrm{H}-1^{\prime}\right), 6.29(t d, J=5.6$ and $16 \mathrm{~Hz}$; H$\left.2^{\prime}\right), 4.19\left(t, J=5.6 \mathrm{~Hz} ; \mathrm{H}-3^{\prime}\right), 4.87\left(d, J=7.7 \mathrm{~Hz} ; \mathrm{H}-1^{\prime \prime}\right), 4.23$ $\left(t, J=7.8 \mathrm{~Hz}, \mathrm{H}-2^{\prime \prime}\right), 4.22\left(t, J=7.6 \mathrm{~Hz}, \mathrm{H}-3^{\prime \prime}\right), 4.21(d d, J=$ 7.6 and $\left.7.8 \mathrm{~Hz}, \mathrm{H}-4^{\prime \prime}\right), 4.05\left(m, \mathrm{H}-5^{\prime \prime}\right), 3.54(t, J=9.6 \mathrm{~Hz}, \mathrm{H}-$ $\left.6^{\prime \prime} \mathrm{a}\right), 3.70\left(d d, J=4.5\right.$ and $\left.9.8 \mathrm{~Hz}, \mathrm{H}-6^{\prime \prime} \mathrm{b}\right), 3.79$ ( $\left.s, \mathrm{C} 2-\mathrm{OMe}\right)$.
${ }^{13} \mathrm{C}$ NMR (100 MHz, acetone- $\left.\mathrm{d}_{6}\right) \delta_{\mathrm{C}}: 150.01$ (C-1), 146.54 (C2), 110.24 (C-3), 132.36 (C-4), 117.11 (C-5), 119.23 (C-6), 128.88 $\left(\mathrm{C}-1^{\prime}\right), 128.87\left(\mathrm{C}-2^{\prime}\right), 62.36\left(\mathrm{C}-3^{\prime}\right), 55.53(\mathrm{C} 2-\mathrm{OMe}), 101.69(\mathrm{C}-$ $\left.1^{\prime \prime}\right), 73.92\left(\mathrm{C}-2^{\prime \prime}\right), 77.07\left(\mathrm{C}-3^{\prime \prime}\right), 70.69\left(\mathrm{C}-4^{\prime \prime}\right), 76.93\left(\mathrm{C}-5^{\prime \prime}\right)$, $61.82\left(\mathrm{C}-6^{\prime \prime}\right)$. On the basis of spectral data, compound 7 was identified as phenylpropane glycoside coniferin (7) [40].

From the fraction F-6, compound 8 was isolated as an amorphous yellow solid, mp $287^{\circ} \mathrm{C}$ [lit: $287^{\circ} \mathrm{C}$ ]. The positive 
FABMS spectrum showed the $[\mathrm{M}+\mathrm{H}]^{+}$ion peak at $m / z 607$, with molecular formula $\mathrm{C}_{29} \mathrm{H}_{34} \mathrm{O}_{14}$. IR ( $\mathrm{KBr}, v_{\max }$ in $\mathrm{cm}^{-1}$ ): 3020, 1746, 1620, 1050, 920. UV $\lambda_{\max }$ (nm): 276 and 284. ${ }^{1} \mathrm{H}$ NMR (400 MHz, CD 3 OD) $\delta_{\mathrm{H}}: 6.28(s, \mathrm{H}-1), 5.48(d, 7.2 \mathrm{~Hz}$; $\mathrm{H}-7), 2.90(m, \mathrm{H}-8), 4.23(t, J=8.8$ and $9.6 \mathrm{~Hz} ; \mathrm{H}-9 \beta), 4.71$ $(t, J=8.4$ and $8.6 \mathrm{~Hz} ; \mathrm{H}-9 \alpha), 6.31\left(s, \mathrm{H}-2^{\prime}, \mathrm{H}-6^{\prime}\right), 4.51(d, J=$ $\left.4.8 \mathrm{~Hz} ;{\mathrm{H}-7^{\prime}}^{\prime}\right), 3.25\left(d d, J=4.8\right.$ and $\left.14 \mathrm{~Hz} ; \mathrm{H}-8^{\prime}\right), 3.72\left(s, \mathrm{C}^{\prime}-\right.$ OMe, C5 $\left.{ }^{\prime}-\mathrm{OMe}\right), 3.99\left(s, \mathrm{C}^{\prime}-\mathrm{OMe}\right), 3.68(s, \mathrm{C} 6-\mathrm{OMe}), 6.02$ $(s,-\mathrm{O}-\mathrm{CH} 2-\mathrm{O}-), 4.54\left(d, J=7.6 \mathrm{~Hz} ; \mathrm{H}^{\prime \prime}{ }^{\prime \prime}\right), 3.28(t, J=9.2 \mathrm{~Hz}$; $\left.\mathrm{H}-2^{\prime \prime}\right), 3.35\left(t, J=7.2 \mathrm{~Hz} ; \mathrm{H}-3^{\prime \prime}\right), 3.41(d d, J=7.2$ y $6.8 \mathrm{~Hz}$; $\left.\mathrm{H}-4^{\prime \prime}\right), 3.43\left(m, \mathrm{H}-5^{\prime \prime}\right), 3.76\left(d d, J=2.2\right.$ and $\left.10 \mathrm{~Hz}, \mathrm{H}-6^{\prime \prime} \mathrm{a}\right)$, $3.84\left(d d, J=5.4\right.$ and $\left.10.2 \mathrm{~Hz}, \mathrm{H}-6{ }^{\prime \prime} \mathrm{b}\right) .{ }^{13} \mathrm{C} \mathrm{NMR}(100 \mathrm{MHz}$, $\left.\mathrm{CD}_{3} \mathrm{OD}\right) \delta_{\mathrm{C}}: 124.26(\mathrm{C}-1), 136.28$ (C-2), 105.74 (C-3), 149.68 (C-4), 135.89 (C-5), 140.26 (C-6), 72.78 (C-7), 39.87 (C-8), 72.39 (C-9), $136.73\left({\mathrm{C}-1^{\prime}}^{\prime}\right), 108.58\left(\mathrm{C}-2^{\prime}\right), 152.89\left(\mathrm{C}-3^{\prime}\right), 136.54$ $\left(\mathrm{C}-4^{\prime}\right), 152.89\left(\mathrm{C}-5^{\prime}\right), 108.58\left(\mathrm{C}-6^{\prime}\right), 45.86\left(\mathrm{C}-7^{\prime}\right), 46.23\left(\mathrm{C}-8^{\prime}\right)$, $176.67\left(\mathrm{C}-9^{\prime}\right), 56.24\left(\mathrm{C}^{\prime}-\mathrm{OMe}, \mathrm{C}^{\prime}-\mathrm{OMe}\right), 60.76\left(\mathrm{C} 4^{\prime}-\mathrm{OMe}\right)$, 60.76 (C6-OMe), 102.34 (-O-CH2-O-), 100.46 (C-1" $\left.{ }^{\prime \prime}\right), 74.87$ $\left(\mathrm{C}-2^{\prime \prime}\right), 77.85\left(\mathrm{C}-3^{\prime \prime}\right), 71.67\left(\mathrm{C}-4^{\prime \prime}\right), 78.13\left(\mathrm{C}-5^{\prime \prime}\right), 63.08\left(\mathrm{C}-6^{\prime \prime}\right)$. On the basis of spectral data, compound 8 was identified as 6-methoxypodophyllotoxin 7-O- $\beta$-D-glucopyranoside [40].

The obtained data were compared with the literature [41-43] (see Supplementary Material Figures 1-6 in Supplementary Material available online at http://dx.doi.org/ $10.1155 / 2015 / 298463)$.

Some studies reported that compounds 1, 2, and 4 possess anti-inflammatory activity [42] while compound 5 has chemopreventive properties. [38]. Even though all of the 8 compounds had been previously reported in members of the genus Linum [44-47], this is the first time that they were identified in Linum scabrellum.

3.2. Cytotoxic Activity of Purified Compounds. The isolated compounds 6, 7, and 8 were evaluated for cytotoxic effect against the above mentioned cell lines. Compounds 7 and 8 were nonactive $\left(\mathrm{IC}_{50} \geq 20 \mu \mathrm{g} / \mathrm{mL}\right.$ ), while compound 6 (6MPTOX) showed an important cytotoxic activity with $\mathrm{IC}_{50}$ values ranging from 0.0632 to $2.7433 \mu \mathrm{g} / \mathrm{mL}$ against the cancer tested cell lines (Table 1). It is important to point out that 6 MPTOX was also toxic against the normal fibroblasts. These data showed that the inhibitory effect of 6MPTOX as well as that of the $\mathrm{CH}_{2} \mathrm{Cl}_{2}: \mathrm{MeOH}$ roots extract of Linum scabrellum is not specific against certain carcinomas but rather exerts a general cell toxic action. Because the important cytotoxic activity demonstrated by 6MPTOX, we decided to investigate the mechanism of action of this compound.

3.3. Effect of 6MPTOX on PC3 Cell Cycle Arrest. The effect of 6MPTOX in the cell cycle progression of PC3 cells was determined at four concentrations: $0.011 \mu \mathrm{M}, 0.005 \mu \mathrm{M}$, $0.002 \mu \mathrm{M}$, and $0.001 \mu \mathrm{M}$. DMSO $(2.55 \mu \mathrm{M}-0.02 \%)$ and PTOX $(0.0024 \mu \mathrm{M})$ were used as negative and positive controls, respectively. Figure 2 displays DNA histograms of PC3 cell cycle. The 6MPTOX induced in PC3 a G2/M phase cell arrest. The effect was dose-dependent since cell arrest in G2/M was declining, while the G1 phase cell population was increasing when the $6 \mathrm{MPTOX}$ concentration decreased. 6MPTOX and PTOX at $0.0002 \mu \mathrm{M}$ induced a similar effect on $\mathrm{G} 2 / \mathrm{M}$ cell arrest with $39.8 \%$ and $41.1 \%$ of $\mathrm{G} 2 / \mathrm{M}$ cell population, respectively. These results suggest that $6 \mathrm{MPTOX}$ efficiently arrest cells at G2/M phase.

3.4. Effect of 6MOTX on Mitotic Arrest. Histone H3 phosphorylated at serine 10 has long been used to identify mitotic cells nuclei in culture cell lines [48]. The proportion of cells exhibiting mitosis in the PC3 cultures was determined using an antibody antiphospho-histone H3, after treatment with 6 MPTOX. The mitotic index was calculated by image analysis. Taxol and PTOX were used as positive controls, while DMSO was used as the negative control. 6MPTOX showed a mitotic index of 0.1 , Taxol of 0.25 , and PTOX of 0.2 , while the negative control displayed a mitotic index of 0.035 (Figure 3 ). These results suggest that $6 \mathrm{MPTOX}$ induces mitotic arrest as did PTOX and Taxol, in contrast to the negative control. Inhibition of tubulin has been implicated in G2/M phase of the cell cycle arrest in various cancer cell lines [49]. It is well known that Taxol stabilizes microtubules protecting them from depolymerization, which blocks cells in mitosis and induces apoptosis [50], in contrast with PTOX, which promotes depolymerization by destabilizing microtubules and arrests the cell cycle in mitosis [51].

Our results showed that $6 \mathrm{MPTOX}$ induced a mitotic cell arrest by the observed high mitotic index and the G2/M cell arrest, suggesting a similar effect as that displayed by PTOX or Taxol. In order to determine the mechanism of action of 6MPTOX, we analyzed the effect of microtubule polymerization by 6MPTOX through disruption of $\alpha / \beta$ tubulin binding.

3.5. Effect of 6MPTOX on the $\alpha$-Tubulin Polymerization. Microtubules are in dynamic equilibrium with tubulin dimers as tubulin is polymerized into microtubules and depolymerized as free tubulin. This dynamic equilibrium is targeted by microtubule disrupting agents [52], which inhibit the organization of the mitotic spindle and arrest chromosomes in metaphase of mitosis [53]. The effect of 6MPTOX on the microtubule polymerization by immunofluorescence of $\alpha$ tubulin was observed in PC3 cells by confocal microscopy. Figure 4(b) shows that treatment with 6MPTOX inhibits the polymerization of microtubules possibly through binding to tubulin, of which effect was also observed by treatment with PTOX (Figure 4(c)). In the negative control (DMSO $0.02 \%$, Figure 4(a)) no effect was appreciated.

These results suggest that 6MPTOX as well as PTOX act as microtubule-destabilizing agents, while cells treated with DMSO $(0.02 \%)$ demonstrated a normal and intact tubulin organization (Figure 4(a)).

3.6. Determination of the Binding Site and Binding Constant $\left(K_{b}\right)$ of 6MPTOX. To corroborate whether 6MPTOX binds to $\alpha / \beta$-tubulin as does PTOX, 6MPTOX was assayed for its ability to displace MTC from its binding at the colchicine site of $\alpha / \beta$-tubulin $[54,55]$. Figure 5 shows fluorescence changes produced by the displacement of MTC binding to tubulin by both 6MPTOX and PTOX. The fluorescence spectra of MTC decreased by $43 \%$ with 6 MPTOX indicating that 6 MPTOX binds to the colchicine binding site, while PTOX decreased $65 \%$. The binding constant for 6 MPTOX was determined 


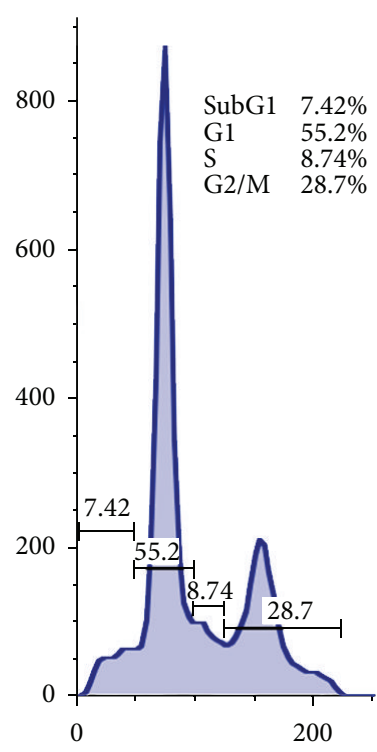

(a)

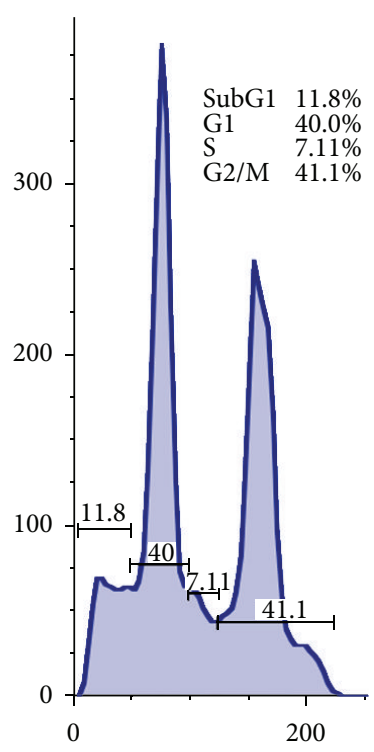

(b)

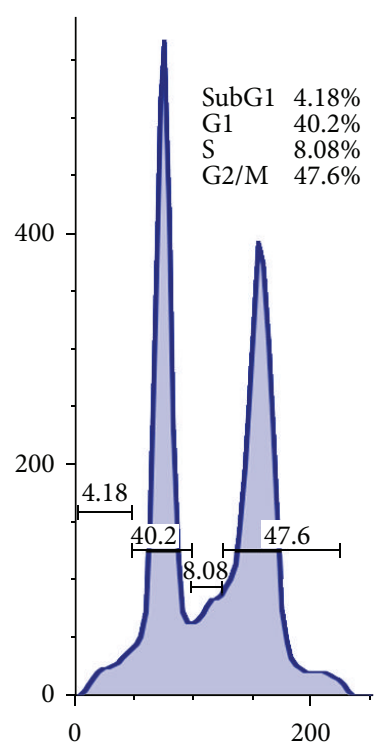

(c)

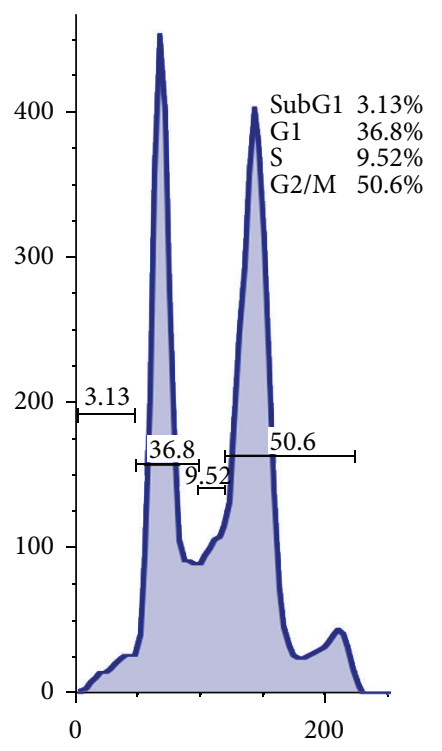

(d)

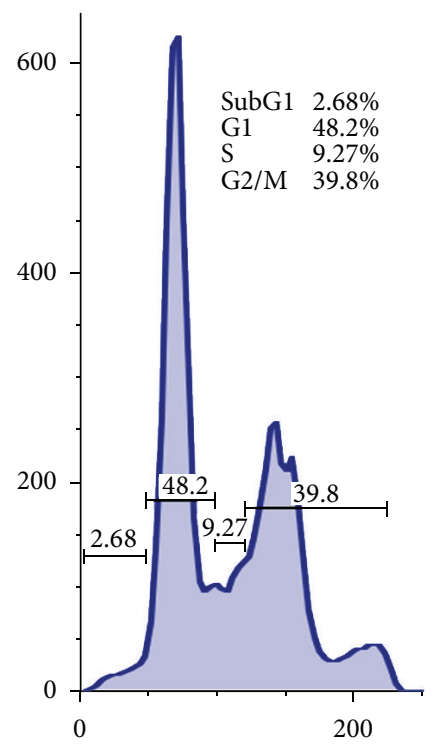

(e)

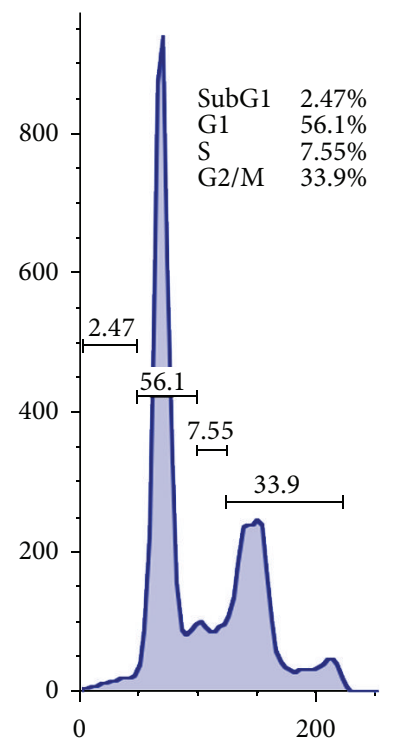

(f)

FIGURE 2: Effect of 6MPTOX on cell cycle in the prostate PC3 cell line. (a) Negative control with DMSO 0.02\%; (b) PC3 cells exposed to $0.002 \mu \mathrm{M}$ PTOX as positive control; (c-f) PC3 cells exposed to different concentrations of 6MPTOX; (c) $0.011 \mu \mathrm{M}$; (d) $0.005 \mu \mathrm{M}$; (e) $0.002 \mu \mathrm{M}$; (f) $0.001 \mu \mathrm{M}$.

as $K_{b}=7.26 \times 10^{6} \mathrm{M}^{-1}$ by displacement of MTC in the colchicine binding site. MTC has $K_{b}=4.7 \times 10^{5} \mathrm{M}^{-1}$ [33], which indicated that $6 \mathrm{MPTOX}$ is a stronger inhibitor when compared to MTC.

3.7. Effect of 6MPTOX on Cellular Death of PC3 Cells. Cell death occurs through at least three morphologically distinct subroutines that have been named apoptosis, autophagy cell death (ACD), and necrosis [56]. Apoptosis is morphologically defined by nuclear shrinkage and fragmentation [57], whereas necrosis is defined by early permeabilization of the plasma membrane [58]. The effect of 6MPTOX on cellular death of prostate cancer cells was determined using four different concentrations. The compound 6MPTOX at a lower concentration of $0.001 \mu \mathrm{M}$ did not show any effect on cell death. When the concentration was increased to $0.002 \mu \mathrm{M}$ some apoptotic bodies were observed (Figure 6(e)); with $0.005 \mu \mathrm{M}$, few cells were in late apoptosis and others were necrotic (orange or red color, Figure 6(f)); and at the highest concentration of $0.011 \mu \mathrm{M}$ the effect caused cell death mainly by necrosis (Figure 6(g)). Three controls were used: boiling water for necrosis, where most of the cells stained in red (Figure 6(c)); $\mathrm{H}_{2} \mathrm{O}_{2}$ for apoptosis, where some of the cells stained in green or orange with apoptotic bodies 


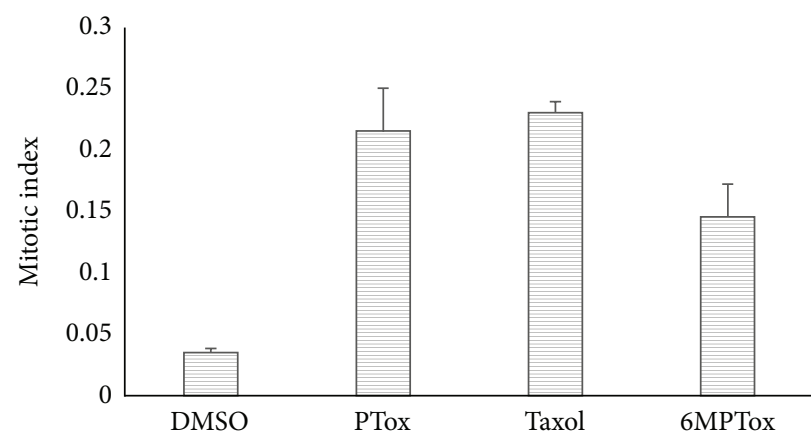

FIGURE 3: Effect of 6MPTOX on mitosis of the prostate cancer cell line PC3.

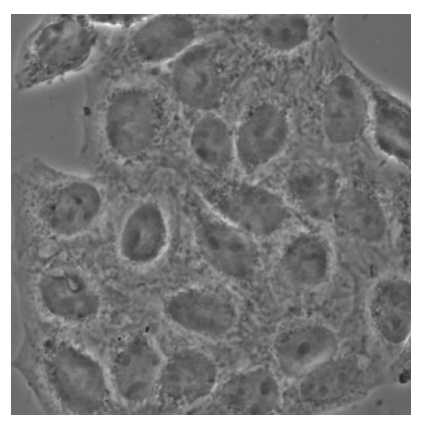

(a)
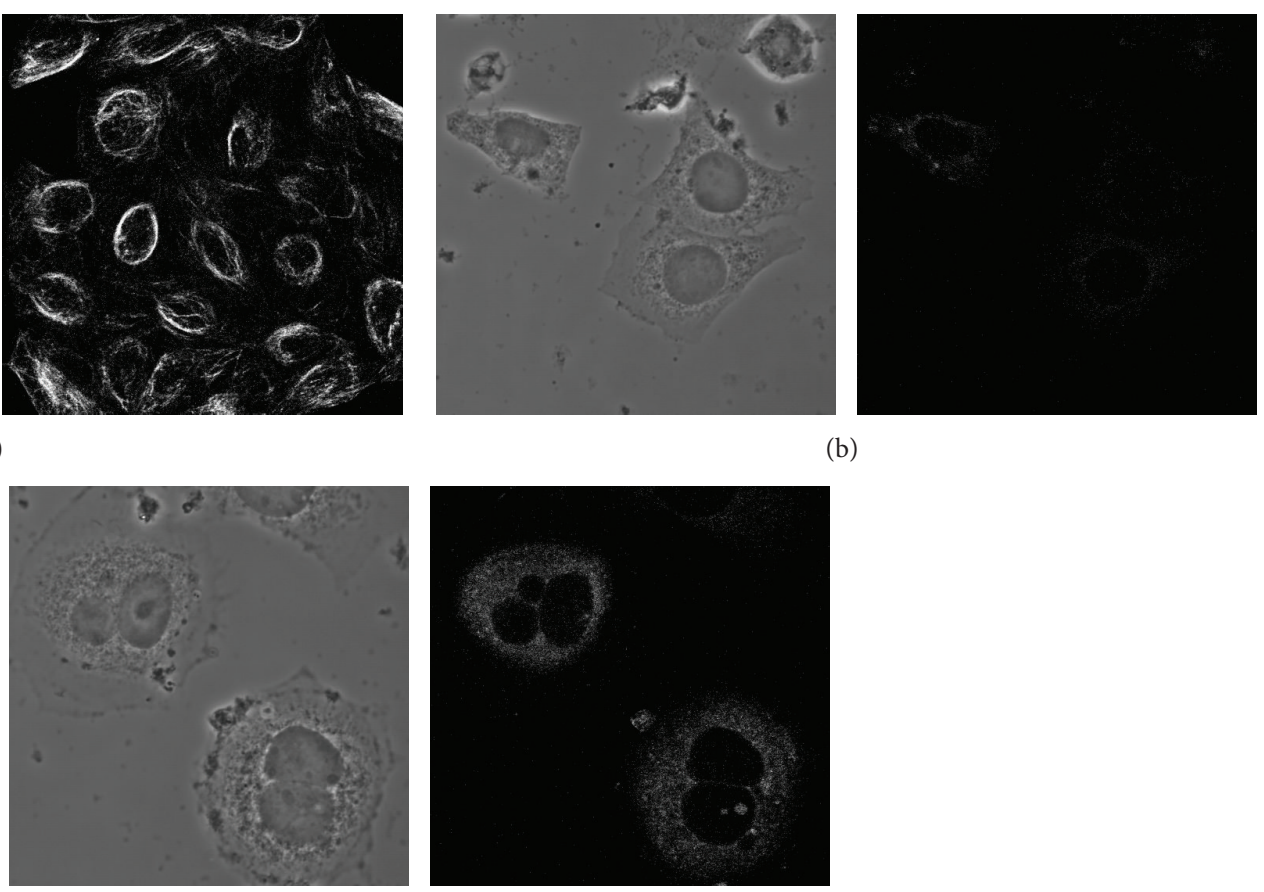

(b)

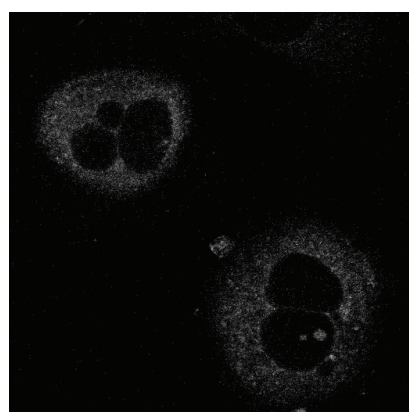

(c)

Figure 4: Effect of microtubules polymerization. (a) DMSO 0.02\%, (b) 6MPTOX, and (c) PTOX.

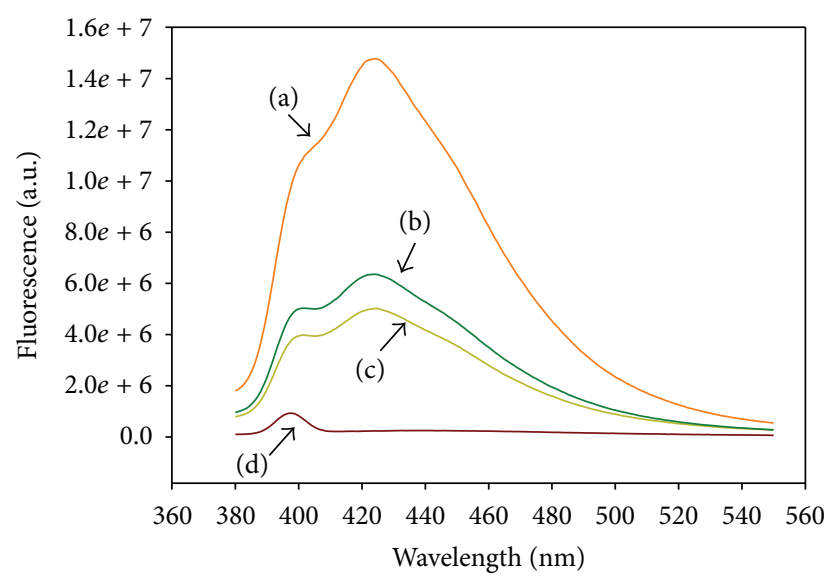

FIGURE 5: Displacement of MTC by 6MPTOX measured with fluorescence, (a) MTC with tubulin, (b) 6MPTOX, (c) PTOX, and (d) MTC. 

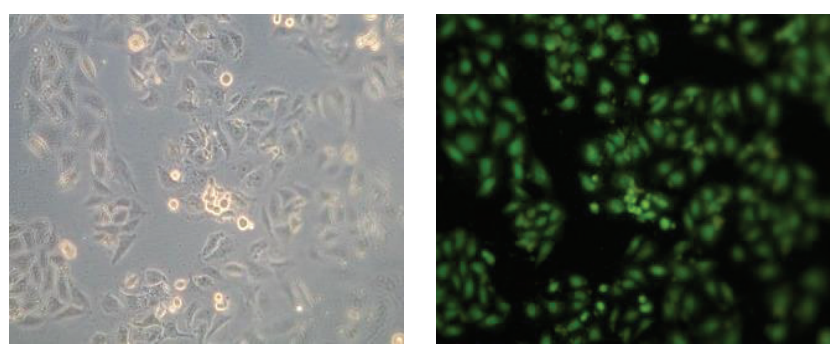

(a)
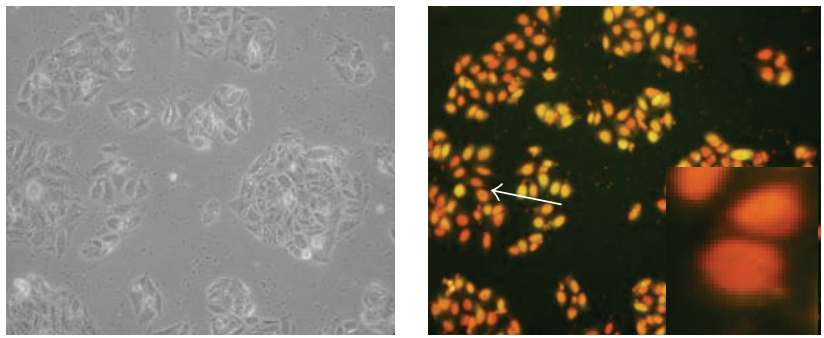

(c)
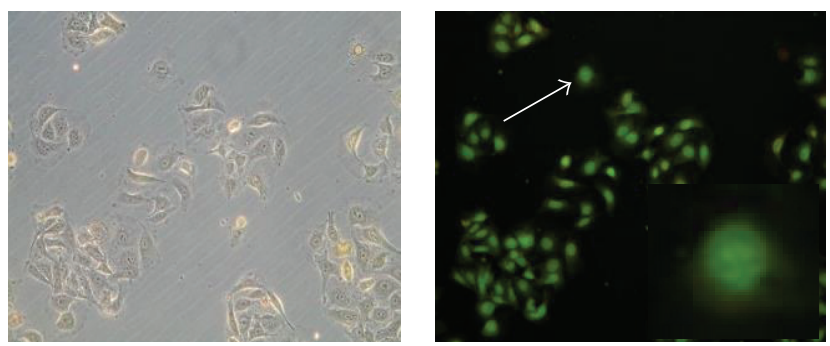

(e)

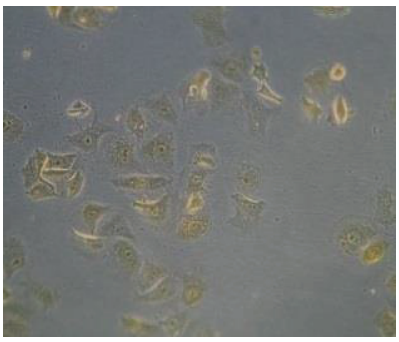

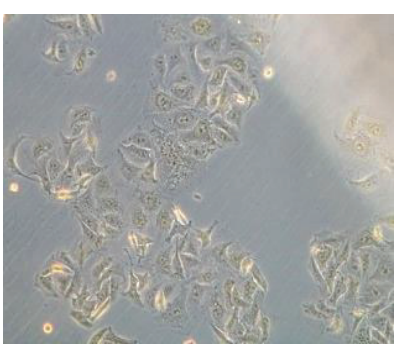

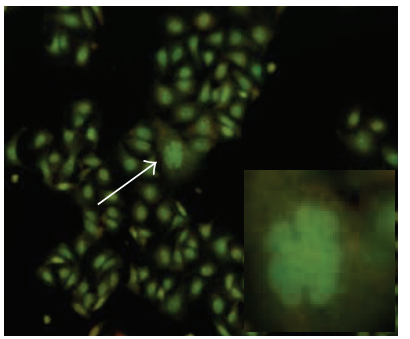

(b)
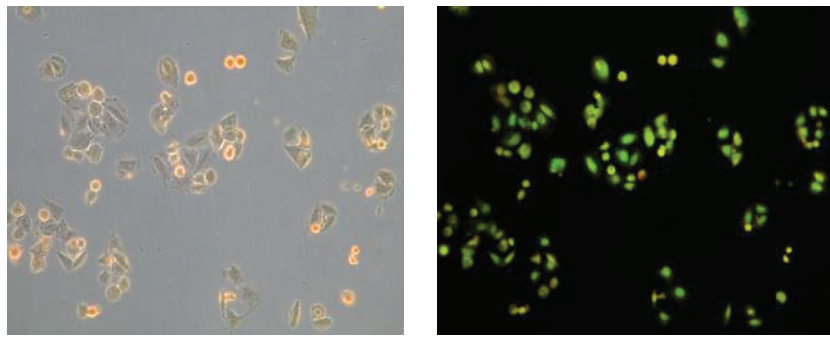

(d)
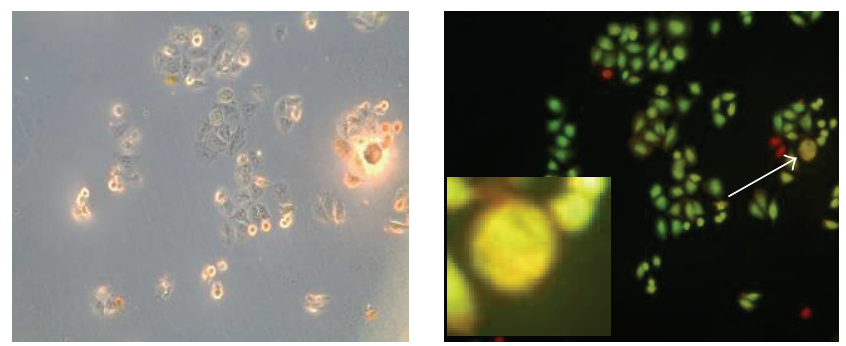

(f)

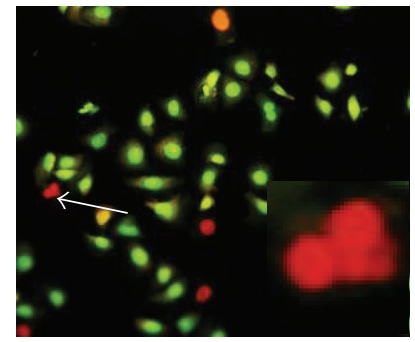

(g)

Figure 6: Effect of 6MPTOX on the prostate cancer cells (PC3). (a) Negative control; (b) apoptosis control; (c) necrosis control; (d-g) cells exposed to different concentrations of $6 \mathrm{MPTOX}$; (d) $0.001 \mu \mathrm{M}$; (e) $0.002 \mu \mathrm{M}$; (f) $0.005 \mu \mathrm{M}$; (6) $0.011 \mu \mathrm{M}$. The arrow points out the cells that were amplified (40x). (b) Apoptotic cells; (c) necrotic cells; (e) apoptotic cells (0.002 $\mu \mathrm{M})$; (f) late apoptosis $(0.005 \mu \mathrm{M})$; (g) necrotic cells $(0.011 \mu \mathrm{M})$.

(Figure 6(b)), and a negative control with most of the cells stained in green (cells without treatment, Figure 6(a)). The effect of 6MPTOX on prostate cancer cells was dose-response, inducing apoptosis followed by necrosis when the concentration increased.

\section{Conclusion}

For the first time, the metabolic content of the Mexican species L. scabrellum was established. Eight compounds including lignans, terpenes, and fatty acids were isolated and identified. This study demonstrated the cytotoxic activity of 6MPTOX toward four selected human carcinomas and against a normal fibroblast cell line. Biochemical and biological experiments showed that 6MPTOX specifically arrested PC3 cells in their G2/M phase as well as a higher mitotic index. Moreover, at its lowest concentration it induces apoptosis as shown by an increase in its subG1 cell population and in stained apoptotic cells. Necrotic cell death was observed at higher concentrations. Data presented in this study show that $6 \mathrm{MPTOX}$ binds at the colchicine binding site of tubulin with a $K_{b}=7.26 \times 10^{6} \mathrm{M}^{-1}$, causing disruption of 
tubulin polymerization. These results showed that $6 \mathrm{MPTOX}$ inhibit tubulin polymerization and arrest cells in G2/M as a mechanism of cytotoxic activity in PC 3 cells. This is the first report describing the mechanism of action of 6MPTOX.

\section{Conflict of Interests}

The authors declare no conflict of interests.

\section{Acknowledgments}

Ivonne Alejandre-García acknowledges fellowship 226354 from CONACYT. The authors thank Dr. Alfonso Lejia from Centro de Ciencias Genómicas, UNAM, for technical assistance. The authors are indebted to Dr. T Fitzgerald from Florida A\&M University for his kind gift of the colchicine analog 2-methoxy-5-(2,3,4-trimethoxyphenyl)2,4,6-cycloheptatrien-1-one (MTC). Partial support from CONACYT (Grants CB 156276 and 222714) is acknowledged. The authors thank Laboratorio Nacional de Estructura de Macromoléculas (Conacyt 251613) for the spectroscopic and mass analyses and support given to J. F. D. from BIPPED2 and BIO2013-42984R from the Ministry of Economy of Spain.

\section{References}

[1] N. Vasilev, R. Ebel, R. Edrada et al., "Metabolic profiling of lignan variability in Linum species of section Syllinum native to Bulgaria," Planta Medica, vol. 74, no. 3, pp. 273-280, 2008.

[2] E. Eich, H. Pertz, M. Kaloga et al., "(-)-Arctigenin as a lead structure for inhibitors of human immunodeficiency virus type1 integrase," Journal of Medicinal Chemistry, vol. 39, no. 1, pp. 86-95, 1996.

[3] K. C. S. Liu, S.-S. Lee, M.-T. Lin et al., "Lignans and tannins as inhibitors of viral reverse transcriptase and human DNA polymerase- $\alpha$ : QSAR analysis and molecular modeling," Medicinal Chemistry Research, vol. 7, no. 1, pp. 168-179, 1997.

[4] H. Hara, T. Fujihashi, T. Sakata, A. Kaji, and H. Kaji, “Tetrahydronaphthalene lignan compounds as potent anti-HIV type 1 agents," AIDS Research and Human Retroviruses, vol. 13, no. 8, pp. 695-705, 1997.

[5] E. L. Ghisalberti, "Cardiovascular activity of naturally occurring lignans," Phytomedicine, vol. 4, no. 2, pp. 151-166, 1997.

[6] M. C. A. Costa and Y. Takahata, "Conformational analysis of synthetic neolignans active against leishmaniasis, using the molecular mechanics method (MM2)," Journal of Computational Chemistry, vol. 18, no. 5, pp. 712-721, 1997.

[7] T. Iwasaki, K. Kondo, T. Nishitani et al., "Arylnaphthalene lignans as novel series of hypolipidemic agents raising highdensity lipoprotein level," Chemical and Pharmaceutical Bulletin, vol. 43, no. 10, pp. 1701-1705, 1995.

[8] T. Kuroda, K. Kondo, T. Iwasaki, A. Ohtani, and K. Takashima, "Synthesis and hypolipidemic activity of diesters of arylnaphthalene lignan and their heteroaromatic analogs," Chemical and Pharmaceutical Bulletin, vol. 45, no. 4, pp. 678-684, 1997.

[9] D. Delorme, Y. Ducharme, C. Brideau et al., "Dioxabicyclooctanyl naphthalenenitriles as nonredox 5-lipoxygenase inhibitors: structure-activity relationship study directed toward the improvement of metabolic stability," Journal of Medicinal Chemistry, vol. 39, no. 20, pp. 3951-3970, 1996.
[10] S. Zacchino, G. Rodríguez, G. Pezzenati, G. Orellana, R. Enriz, and M. G. Sierra, "In vitro evaluation of antifungal properties of 8.O.4'-Neolignans," Journal of Natural Products, vol. 60, no. 7, pp. 659-662, 1997.

[11] S. Rantapaa-Dahlqvist, G. Landberg, G. Roos, and B. Norberg, "Cell cycle effects of the anti-rheumatic agent CPH82," British Journal of Rheumatology, vol. 33, no. 4, pp. 327-331, 1994.

[12] T. Lerndal and B. Svensson, "A clinical study of CPH 82 vs. methotrexate in early rheumatoid arthritis," Rheumatology, vol. 39, no. 3, pp. 316-320, 2000.

[13] B. Leander and K. Rosen, "Medicinal used for podophyllotoxin," US patent: 4, pp. 788, 1988.

[14] T. Iwasaki, K. Kondo, T. Kuroda et al., "Novel selective PDE IV inhibitors as antiasthmatic agents. Synthesis and biological activities of a series of 1-aryl-2,3-bis(hydroxymethyl)naphthalene lignans," Journal of Medicinal Chemistry, vol. 39, no. 14, pp. 2696-2704, 1996.

[15] Y. Damayanthi and J. W. Lown, "Podophyllotoxins: current status and recent developments," Current Medicinal Chemistry, vol. 5, no. 3, pp. 205-252, 1998.

[16] K. R. Hande, "Etoposide: four decades of development of a topoisomerase II inhibitor," European Journal of Cancer, vol. 34, no. 10, pp. 1514-1521, 1998.

[17] S. Hemmati, A. Mohagheghzadeh, and A. W. Alfermann, "Quantification of aryltetralin lignans in Linum album organs and in vitro cultures," Iranian Journal of Pharmaceutical Sciences, vol. 2, no. 1, pp. 47-56, 2006.

[18] B. Konuklugil, T. J. Schmidt, and A. W. Alfermann, "Accumulation of lignans in suspension cultures of Linum mucronatum ssp. Armenum (Bordz.) Davis," Zeitschrift fur NaturforschungSection C: Journal of Biosciences, vol. 56, no. 11, pp. 1164-1165, 2001.

[19] C. Dumontet and M. A. Jordan, "Microtubule-binding agents: a dynamic field of cancer therapeutics," Nature Reviews Drug Discovery, vol. 9, no. 10, pp. 790-803, 2010.

[20] D. C. Ayres and J. D. Loike, Lignans, Chemical, Biological and Clinical Properties, Cambridge University Press, Cambridge, UK, 1st edition, 1990.

[21] A. D. Buss, R. D. Waigh, and M. E. Wolff, Natural Products as Leads for New Pharmaceuticals, John Wiley \& Sons, New York, NY, USA, 1st edition, 1995.

[22] M. Gordaliza, M. A. Castro, J. M. M. del Corral, and A. San Feliciano, "Antitumor properties of podophyllotoxin and related compounds," Current Pharmaceutical Design, vol. 6, no. 18, pp. 1811-1839, 2000.

[23] W. van Uden, B. Homan, H. J. Woerdenbag et al., "Isolation, purification, and cytotoxicity of 5-methoxypodophyllotoxin, a lignan from a root culture of Linum flavum," Journal of Natural Products, vol. 55, no. 1, pp. 102-110, 1992.

[24] A. M. Rojas, M. A. Mendieta, M. Y. Antúnez et al., "Cytotoxic podophyllotoxin type-lignans from the steam bark of Bursera fagaroides var. Fagaroides," Molecules, vol. 17, no. 8, pp. 95069519, 2012.

[25] M. Á. Castro, J. M. M. del Corral, P. A. García et al., "Synthesis and biological evaluation of new podophyllic aldehyde derivatives with cytotoxic and apoptosis-inducing activities," Journal of Medicinal Chemistry, vol. 53, no. 3, pp. 983-993, 2010.

[26] A. Nepomuceno and M. Ishiki, "Las plantas empleadas para el tratamiento de las infecciones respiratorias en los altos de Chiapas (México)," Etnobiología, vol. 8, no. 11, pp. 11-30, 2010. 
[27] C. Zolla and A. Argueta, Atlas de las Plantas de la Medicina Tradicional Mexicana, Biblioteca de Medicina Tradicional Mexicana, Instituto Nacional Indigenista, México, Mexico, 1st edition, 1994.

[28] J. Rzedowski and G. Rzedowsky, Flora del Bajío y Regiones Adyacentes, vol. 6, Instituto de Ecología, 1992.

[29] A. Muir and N. Westcot, Flax: The Genus Linum, Taylor \& Francis, 3rd edition, 2003.

[30] E. Lautié, R. Quintero, M.-A. Fliniaux, and M.-L. Villarreal, "Selection methodology with scoring system: application to Mexican plants producing podophyllotoxin related lignans," Journal of Ethnopharmacology, vol. 120, no. 3, pp. 402-412, 2008.

[31] P. Skehan, R. Storeng, D. Scudiero et al., "New colorimetric cytotoxicity assay for anticancer-drug screening," Journal of the National Cancer Institute, vol. 82, no. 13, pp. 1107-1112, 1990.

[32] M. Suffness and J. M. Pezzuto, "Assays related to cancer drug discovery," in Methods in Plant Biochemistry: Assays for Bioactivity, 6, K. Hostettmann, Ed., pp. 71-133, Academic Press, London, UK, 1990.

[33] G. la Regina, M. C. Edler, A. Brancale et al., "Arylthioindole inhibitors of tubulin polymerization. 3. Biological evaluation, structure-activity relationships and molecular modeling studies," Journal of Medicinal Chemistry, vol. 50, no. 12, pp. 28652874, 2007.

[34] R. M. Buey, I. Barasoain, E. Jackson et al., "Microtubule interactions with chemically diverse stabilizing agents: thermodynamics of binding to the paclitaxel site predicts cytotoxicity," Chemistry and Biology, vol. 12, no. 12, pp. 1269-1279, 2005.

[35] G.-Y. Yang, J. Liao, K. Kim, E. J. Yurkow, and C. S. Yang, "Inhibition of growth and induction of apoptosis in human cancer cell lines by tea polyphenols," Carcinogenesis, vol. 19, no. 4, pp. 611-616, 1998.

[36] S. Kasibhatla, G. Amarante-Mendes, D. Finucane, T. Brunner, and E. Bossy-Wetzel, "Acridine orange/ethidium bromide (AO/ EB) staining to detect apoptosis," Cold Spring Harbor Protocols, vol. 2006, no. 3, p. 4493, 2006.

[37] S. Mohan, A. Bustamam, S. Ibrahim et al., "In vitro ultramorphological assessment of apoptosis on CEMss induced by linoleic acid-rich fraction from Typhonium flagelliforme tuber," Evidence-Based Complementary and Alternative Medicine, vol. 2011, Article ID 421894, 12 pages, 2011.

[38] L. Fini, E. Hotchkiss, V. Fogliano et al., "Chemopreventive properties of pinoresinol-rich olive oil involve a selective activation of the ATM-p53 cascade in colon cancer cell lines," Carcinogenesis, vol. 29, no. 1, pp. 139-146, 2008.

[39] A. San Feliciano, J. M. M. del Corral, M. Gordaliza, and A. Castro, "Lignans from Juniperus sabina," Phytochemistry, vol. 29, no. 4, pp. 1335-1338, 1990.

[40] A. J. Broomhead and P. M. Dewick, "Aryltetralin lignans from Linum flavum and Linum capitatum," Phytochemistry, vol. 29, no. 12 , pp. 3839-3844, 1990.

[41] C. van Minh, N. X. Nhiem, H. T. Yen et al., "Chemical constituents of Trichosanthes kirilowii and their cytotoxic activities," Archives of Pharmacal Research, 2015.

[42] G. Correa, V. Da Costa Abreu, D. Martins et al., "Antiinflamatory and antimicrobial activities of steroids and triterpenes isolated from aerial parts of Justicia acuminatissima (Acanthaceae)," International Journal of Pharmacy and Pharmaceutical Sciences, vol. 6, no. 6, pp. 75-81, 2014.

[43] T. J. Schmidt, M. Klaes, and J. Sendker, "Lignans in seeds of Linum species," Phytochemistry, vol. 82, pp. 89-99, 2012.
[44] A. Mohagheghzadeh, A. Gholami, M. Soltani, S. Hemmati, and A. W. Alfermann, "Linum mucronatum: organ to organ lignan variations," Zeitschrift für Naturforschung C, vol. 60, no. 5-6, pp. 508-510, 2005.

[45] B. Konuklugil, I. Ionkova, N. Vasilev et al., "Lignans from Linum species of sections Syllinum and Linum," Natural Product Research, vol. 21, no. 1, pp. 1-6, 2007.

[46] S. Kumar, F. M. You, S. Duguid, H. Booker, G. Rowland, and S. Cloutier, "QTL for fatty acid composition and yield in linseed (Linum usitatissimum L.)," Theoretical and Applied Genetics, vol. 128, no. 5, pp. 965-984, 2015.

[47] S. Hemmati, C. B. I. von Heimendahl, M. Klaes, A. W. Alfermann, T. J. Schmidt, and E. Fuss, "Pinoresinol-lariciresinol reductases with opposite enantiospecificity determine the enantiomeric composition of lignans in the different organs of Linum usitatissimum L.," Planta Medica, vol. 76, no. 9, pp. 928-934, 2010.

[48] M. J. Hendzel, Y. Wei, M. A. Mancini et al., "Mitosis-specific phosphorylation of histone $\mathrm{H}_{3}$ initiates primarily within pericentromeric heterochromatin during G2 and spreads in an ordered fashion coincident with mitotic chromosome condensation," Chromosoma, vol. 106, no. 6, pp. 348-360, 1997.

[49] S. Kasibhatla, H. Gourdeau, K. Meerovitch et al., "Discovery and mechanism of action of a novel series of apoptosis inducers with potential vascular targeting activity," Molecular Cancer Therapeutics, vol. 3, no. 11, pp. 1365-1373, 2004.

[50] A. W. Heldman, L. Cheng, G. M. Jenkins et al., "Paclitaxel stent coating inhibits neointimal hyperplasia at 4 weeks in a porcine model of coronary restenosis," Circulation, vol. 103, no. 18, pp. 2289-2295, 2001.

[51] M. Gordaliza, P. A. García, J. M. M. del Corral, M. A. Castro, and M. A. Gómez-Zurita, "Podophyllotoxin: distribution, sources, applications and new cytotoxic derivatives," Toxicon, vol. 44, no. 4, pp. 441-459, 2004.

[52] A. Kamal, T. Srinivasa Reddy, S. Polepalli et al., "Synthesis and biological evaluation of podophyllotoxin congeners as tubulin polymerization inhibitors," Bioorganic \& Medicinal Chemistry, vol. 22, no. 19, pp. 5466-5475, 2014.

[53] S. B. Hastie, "Interactions of colchicine with tubulin," Pharmacology \& Therapeutics, vol. 51, no. 3, pp. 377-401, 1991.

[54] T. J. Fltzgerald, "Molecular features of colchicine associated with antimitotic activity and inhibition of tubulin polymerization," Biochemical Pharmacology, vol. 25, no. 12, pp. 1383-1387, 1976.

[55] F. J. Medrano, J. M. Andreu, M. J. Gorbunoff, and S. N. Timasheff, "Roles of ring C oxygens in the binding of colchicine to tubulin," Biochemistry, vol. 30, no. 15, pp. 3770-3777, 1991.

[56] G. Kroemer, L. Galluzzi, P. Vandenabeele et al., "Classification of cell death: recommendations of the nomenclature committee on cell death 2009," Cell Death \& Differentiation, vol. 16, no. 1, pp. 3-11, 2009.

[57] J. F. Kerr, A. H. Wyllie, and A. R. Currie, "Apoptosis: a basic biological phenomenon with wide-ranging implications in tissue kinetics," British Journal of Cancer, vol. 26, no. 4, pp. 239-257, 1972.

[58] A. Degterev and J. Yuan, "Expansion and evolution of cell death programmes," Nature Reviews Molecular Cell Biology, vol. 9, no. 5, pp. 378-390, 2008. 


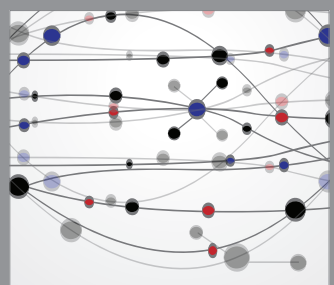

The Scientific World Journal
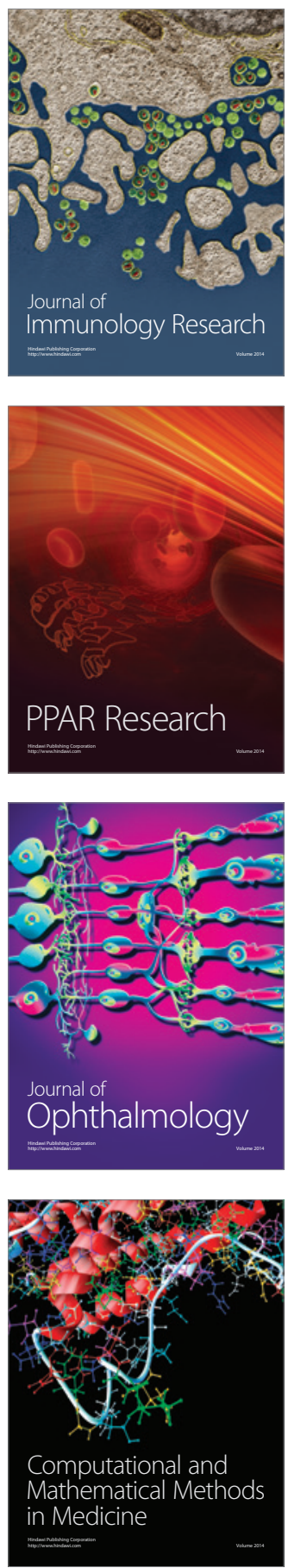

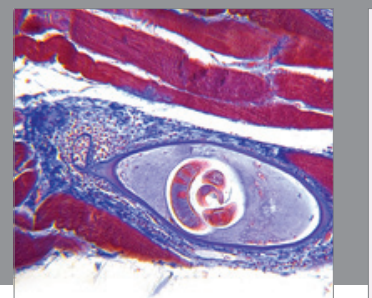

Gastroenterology

Research and Practice
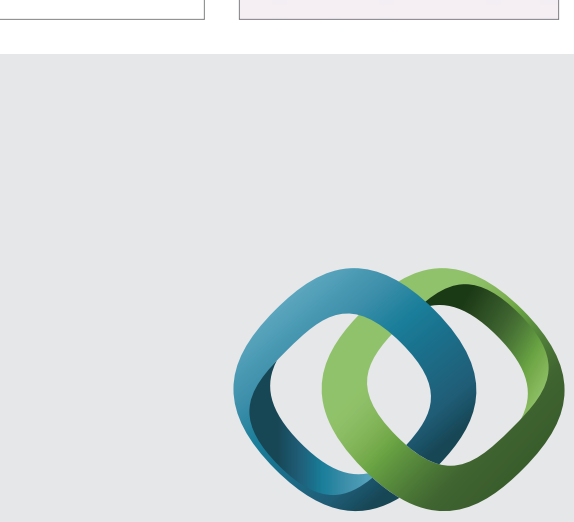

\section{Hindawi}

Submit your manuscripts at

http://www.hindawi.com
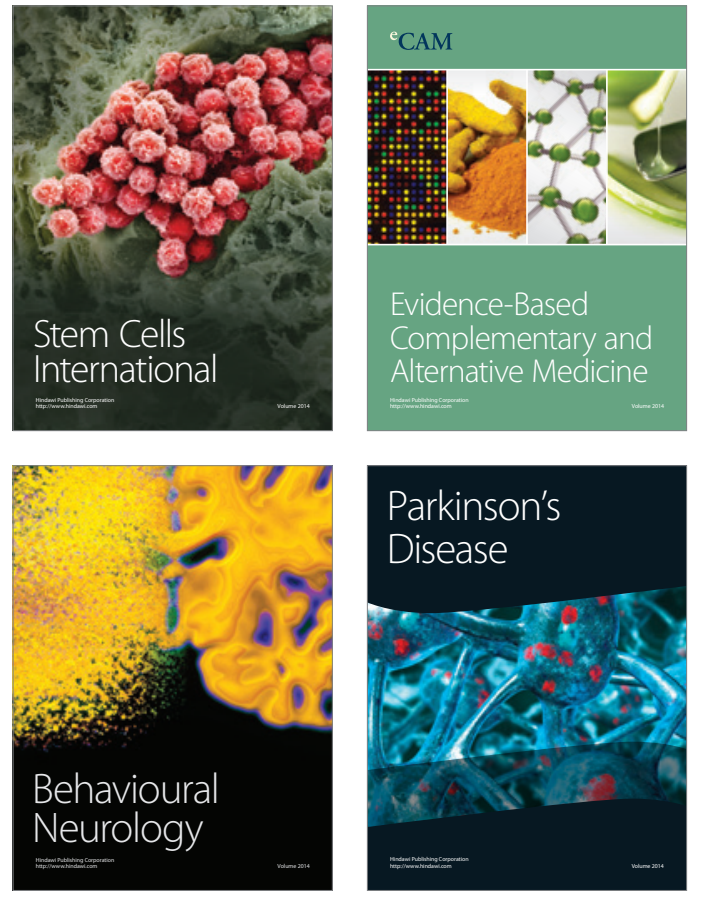
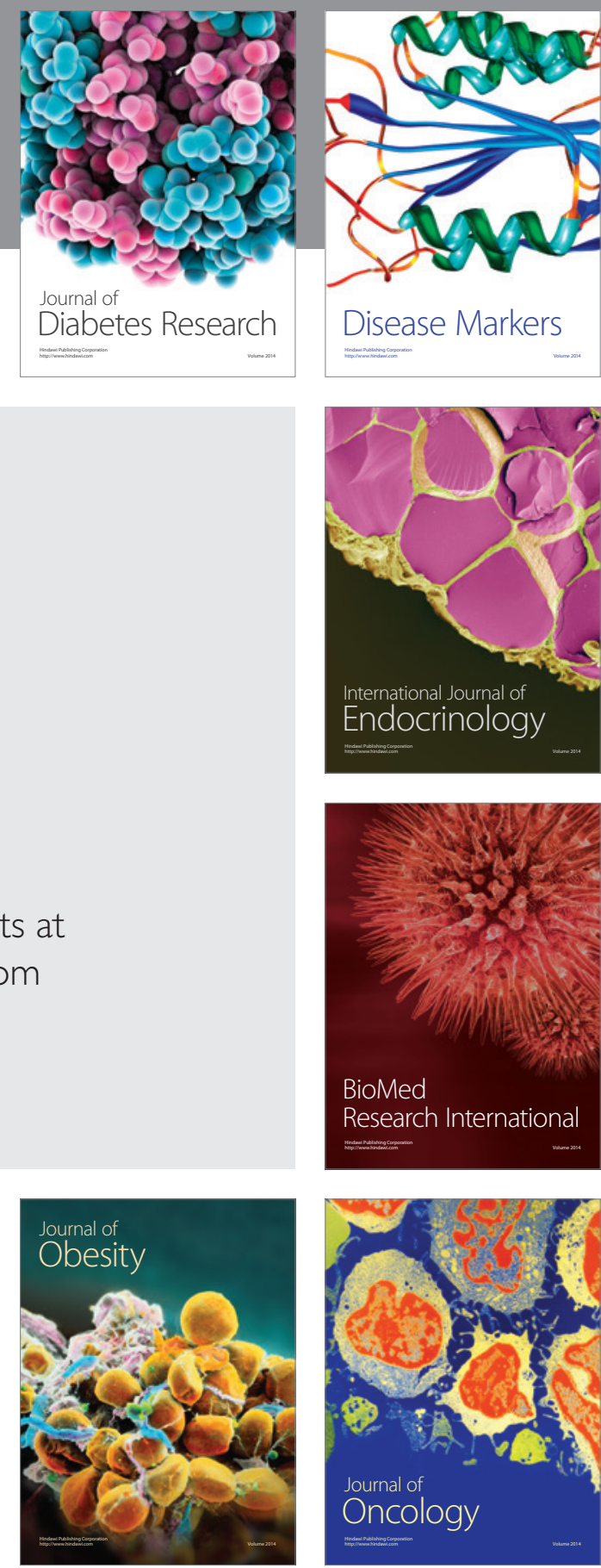

Disease Markers
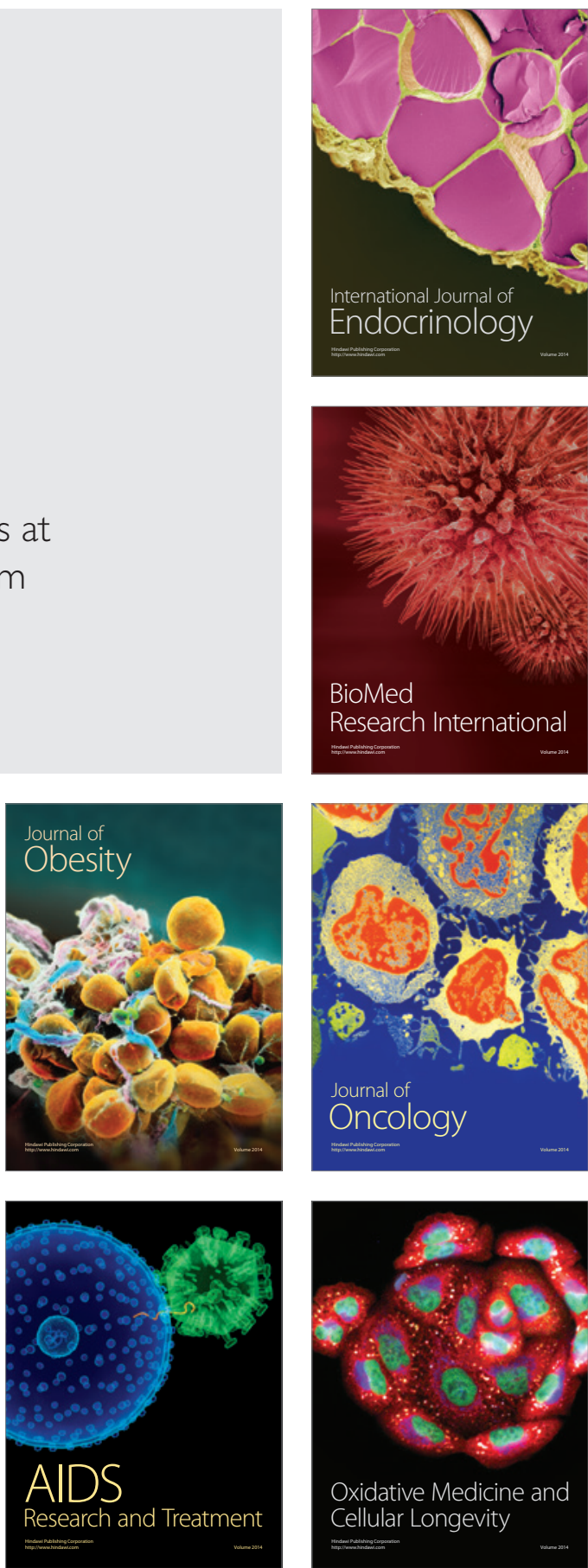